\title{
KESIAPAN PUSAT LAYANAN KESEHATAN (PLK) B UNAIR MENGHADAPI AKREDITASI KLINIK PRATAMA
}

\author{
THE READINESS OF AIRLANGGA HEALTH CARE CENTERS (AHCC) B FACED ACCREDITATION FOR \\ FIRST LEVEL CLINICS
}

Putri Ayu Anggraeny, Ernawaty

Fakultas Kesehatan Masyarakat, Universitas Airlangga, Surabaya

E-mail:puteput@gmail.com

\begin{abstract}
PLK B Unair is one of the first level clinic that owned by Airlangga University in cooperation with Social Security Agency of Health (BPJS). As mandatory by act, PLK B Unair should start to prepare to reach accreditation for first level clinics to realizing quality assurance for health services. This study aimed to know the early achievement of accreditation assessment in accordance with the guidelines Health Ministerial Regulation No. 46/2015. This was descriptive observational study with cross sectional design The documents were traced to identify the completeness according the instrument, and interviewed was did to know some procedures. The results showed that the achievement there is only $51 \%$ of all elements assessment in accreditation standards for the readiness of PLK to faced acreditation. Research recomendation leading to the formation of the team for the preparation of accreditation.
\end{abstract}

Keywords: accreditation, first level clinics, quality assurance, accreditation standards

\section{PENDAHULUAN}

Kesehatan adalah hak asasi manusia sebagai salah satu kebutuhan dasar hidup yang selayaknya dijamin oleh Negara sesuai UndangUndang RI Nomor 40 Tahun 2004.Maka Pemerintah menyelenggarakan Program Jaminan Kesehatan Nasional (JKN) atas pelaksanaan jaminan kesehatan masyarakat dan menunjuk Badan Penyelenggara Jaminan Sosial (BPJS) Kesehatan sebagai penyelenggara program.BPJS Kesehatan bertujuan untuk mewujudkan terselenggaranya pemberian jaminan terpenuhinya kebutuhan dasar hidup yang layak bagi setiap peserta dan atau keluarganya (Humas BPJS Kesehatan, 2013).

Di era JKN, pelayanan kesehatan dilakukan secara berjenjang dimulai dari Fasilitas Kesehatan Tingkat Pertama (FKTP) sebagai Penyedia Pelayanan Kesehatan (PPK) tingkat pertama yang akan melayani pasien BPJS Kesehatankemudian dirujuk ke fasilitas kesehatan tingkat selanjutnya jika membutuhkan. Humas BPJS
Kesehatan (2016) menjelaskan sistem rujukan tersebut menyebabkan FKTP menjadi gerbang utama peserta BPJS Kesehatan dalammengakses pelayanan kesehatan.Keadaan tersebut menjadi tantangan tersendiri bagi setiap FKTP untuk mempertahankan mutu pelayanan kesehatannya.Oleh karena itu, menurut informasi Hukormas BUK Kemenkes RI (2015) menetapkan bahwa indikator mutu pelayanan kesehatan yaitu akreditasi.Akreditasi diperlukan dengan tujuan meningkatkan mutu sehingga semua FKTP yang bekerjasama dengan BPJS Kesehatan khususnya memiliki mutu yang bisa diunggulkan dan mampu memberikan pelayanan yang berkualitas dan sesuai standar.

Pusat Layanan Kesehatan (PLK) Universitas Airlangga (Unair) merupakan klinik pratama yang berada di bawah naungan Unair.PLK Unair memiliki tugas pokok dan fungsi sesuai SK yang ditetapkan yaitu untuk memfasilitasi melayani dan advokasi pemeliharaan kesehatan dan 
kebugaran civitas akademika.SK tersebut menunjukkan PLK Unair awalnya hanya melayani mahasiswa kemudian melayani seluruh civitas akademika dan masyarakat umum.Sejak tanggal 1 Nopember 2014, dua (2) klinik pratama PLK Unair, yaitu PLK B dan PLK C bekerjasama dengan BPJS Kesehatan sebagai Fasilitas Kesehatan Tingkat Pertama (FKTP). Penamaan klinik B dan C berdasarkan lokasi klinik yang terletak di Kampus B dan C Unair.Saat ini, PLK Unair melayani pasien peserta BPJS Kesehatan dan juga pasien non peserta BPJS Kesehatan.

Laporan kunjungan PLK Unair (2015) menunjukkan jumlah peserta BPJS Kesehatan yang terdaftar di PLK B Unair terhitung sejak tahun 2015 terlihat peningkatan pada setiap bulannya. Peningkatan ini tentunya seiring dengan visi dari PLK Unair yaitu menjadi FKTP milik Perguruan Tinggi yang terbaik di Indonesia. Mewujudkan visi tersebut tentunya menjadikan PLK B Unair harus senantiasa mengupayakan penjaminan mutu dalam pemberian pelayanan kesehatan. Upaya penjaminan mutu tersebut dapat dilakukan dengan mengikutsertakan PLK B Unair dalam akreditasi klinik pratama. Oleh karena itu berdasarkan diseminasi hasil uji coba implementasi akreditasi klinik pratama oleh Kemenkes RI hingga tahun 2015 serta dalam rangka upaya penjaminan mutu maka penelitian ini bertujuan mengetahui kesiapann awal PLK B Unair dalam menghadapi akreditasi klinik pratama yang dapat dijadikan acuan bagi PLK B Unair sebelum akreditasi.

\section{PUSTAKA}

\section{Klinik Pratama}

Fasilitas pelayanan kesehatan adalah tempat yang digunakan untuk menyelenggarakan upaya pelayanan kesehatan, baik berupa upaya promotif, preventif, kuratif maupun rehabilitatif yang dilakukan oleh pemerintah, pemerintah daerah atau masyarakat. Pelayanan kesehatan tingkat pertama yaitu pelayanan kesehatan dasar yang diberikan oleh dokter dan dokter gigi di puskesmas, puskesmas perawatan, tempat praktik perorangan, klinik pratama, klinik umum di balai/lembaga pelayanan kesehatan, dan rumah sakit pratama (Permenkes Nomor 1 Tahun 2012)

Organisasi pelayanan kesehatan di Indonesia jika dilihat dari pengelolanya terdiri dari pemerintah dan swasta, organisasi yang dikelola pemerintah antara lain puskesmas, rumah sakit dan balai kesehatan sedangkan yang disediakan swasta antara lain klinik, praktik dokter, praktik bidan, rumah sakit bersalin, rumah sakit, apotek, serta laboratorium swasta (Maharani, 2009).Klinik pratama menurut penjelasan tersebut diketahui merupakan salah satu organisasi pelayanan kesehatan yang memberikan fasilitas pelayanan kesehatan swasta.

Permenkes Nomor 46 Tahun 2015 tentang Akreditasi Puskesmas, Klinik Pratama, Tempat Praktik Mandiri Dokter, dan Tempat Praktik Mandiri Dokter Gigi menjelaskan bahwa Klinik Pratama adalah fasilitas pelayanan kesehatan yang menyelenggarakan pelayanan kesehatan perseorangan dengan menyediakan pelayanan medik dasar baik umum maupun khusus. Klinik pratama merupakan salah satu bentuk dari FKTP. 


\section{Akreditasi menurut Permenkes Nomor 46 Tahun}

2015

Akreditasi merupakan proses pengamatan yang dilakukan terhadap pelayanan kesehatan yang berpartisipasi untuk memenuhi kriteria dan standar akreditasi yang telah ditentukan. Akreditasi ini dilaksanakan oleh lembaga akreditasi yang professional.Tujuan utama akreditasi adalah untuk pembinaan peningkatan mutu, kinerja melalui perbaikan yang berkesinambungan terhadap sistem manajemen, sistem manajemen mutu dan sistem penyelenggaraan pelayanan klinis, serta penerapan manajemen risiko dan bukan sekedar penilaian mendapatkan sertifikat akreditasi.

Berdasarkan beberapa pustaka lainnya akreditasi merupakan kompetensi suatu lembaga dalam melakukan kegiatan berupa pengakuan formal yang diberikan oleh badan akreditasi terhadap kesesuaian tertentu.Akreditasi merupakan kegiatan yang mengkaji semua hal sebagai bagian dari proses.Hal yang dikaji berkaitan dengan struktur yang ada didalamnya (Poerwarni dan Evie, 2006) Tujuannya untuk peningkatan standar yang berkelanjutan dan berkesinambungan (Accreditation Commision for Health Care, 2016).Hasil penelitian Shaw et. al (2014) pada 73 rumah sakit di Eropa menunjukkan bahwa akreditasi berpengaruh terhadap manajemen mutu dari pelayanan yang diberikan. Akreditasi sangat berkaitan utamanya dalam hal kepemimpinan klinis dan sistem keselamatan pasien.

Secara ringkas, dapat disimpulkan akreditasi merupakan sebuah kegiatan yang dilakukan untuk mendapatkan pengakuan formal terhadap pencapaian suatu standar.Pencapaian tersebut utamanya berupa peningkatan mutu dan kinerja yang berkesinambungan.Status yang ditetapkan sesuai dengan pencapaian dari organisasi pelayanan kesehatan tersebut.

Permenkes Nomor 46 Tahun 2015 adalah kebijakan yang menyusun standar dan instrumen penilaian akreditasi Klinik dalam menyediakan pelayanan klinis tingkat pertama kepada masyarakat.Pada pasal 3 dan 4 dijelaskan bahwa Klinik Pratama wajib terakreditasi yang dapat dilakukan setiap 3 (tiga) tahun.Penetapan status akreditasi merupakan hasil akhir survey akreditasi oleh surveyor dan keputusan rapat lembaga independen penyelenggara akreditasi.Penetapan tersebut dibuktikan dengan adanya sertifikat akreditasi.Status Akreditasi Klinik Pratama terdiri dari (1) Tidak terakreditasi; (2) Terakreditasi dasar; (3) Terakreditasi madya; dan (4) Terakreditasi paripurna. Standar akreditasi Klinik Pratama disusun dalam 4 Bab, yaitu : Bab I Kepemimpinan dan Manajemen Klinik (KMK); Bab II Layanan Klinis yang Berorientasi Pasien (LKBP); Bab III Manajemen Penunjang Layanan Klinis (MPLK) dan Bab IV Peningkatan Mutu Klinis dan Keselamatan Pasien. Masing-masing dari bab tersebut memiliki beberapa standar yang terdiri dari kriteria dan elemen penilaiannya masing-masing.

Bab I mengenai Kepemimpinan dan Manajemen Klinik (KMK) ini terdiri atas enamstandar kriteria dan tersusun atas 29 kriteria yang keseluruhan berjumlah 122 elemen penilaian. Setiap elemen penilaian dalam bab ini merujuk pada hal terkait teknis dari klinik. Standar tersebut antara lain 
persyaratan pendirian dan perijinan, ketenagaan, tata kelola, hak dan kewajiban penggunana pelayanan, kontrak pihak ketiga serta pemeliharaan sarana dan prasarana.

Bab II mengenai Layanan Klinis yang Berorientasi pasien (LKBP) terdiri atas 10 standar yang terbagi ke dalam 34 kriteria.Jumlah seluruh elemen penilaian dari kriteria tersebut adalah 151 elemen. Standar akreditasi dalam bab ini mengenai standar akan pelayanan dari pendaftaran hingga pemulangan dan tindak lanjut.

Bab III standar akreditasi mengenai Manajemen Penunjang Layanan Klinis (MPLK) yaitu sebanyak tujuh dengan jumlah kriteria sebanyak 35 kriteria.Keseluruhan elemen penilaian berjumlah 172 elemen. Standar dalam akreditasi ini mengenai pelayanan penunjang yang ada di klinik hingga tata kelolanya, baik peralatan maupun sumberdaya lain yang dimiliki.

Bab IV mengenai Peningkatan Mutu Klinis dan Keselamatan Pasien terdiri dari 4 standar dengan jumlah kriteria sebanyak 12. Keseluruhan elemen dalam bab ini terdiri atas 58 elemen. Adapun standar dalam bab ini meliputi perencanaan, monitoring serta evaluasi terkait mutu layanan klinis dan keselamatan.

\section{Penjaminan Mutu}

Penjaminan mutu (quality assurance) merupakan konsep yang bertujuan mewujudkan terjaminnya mutu pelayanan kesehatan secara berkesinambungan berdasarkan standar yang telah ditetapkan. Pencapaiannya lebih ditekankan pada proses pelayanan yang sesuai dengan standar sehingga mencegah terjadinya pelayanan yang tidak memenuhi standar. Penjaminan mutu yang berkesinambungan dapat terlaksana jika diterapkan sistem mutu dalam pengelolaan organisasi yang baik. Keadaan tersebut membuat organisasi akan berupaya untuk memberikan pelayanan bahkan melebihi standar. Keadaan tersebut karena berfokus pada kepuasan pelanggan internal dan eksternal (Bustami, 2011).Penjaminan mutu merupakan salah satu bentuk peningkatan kualitas pelayanan.Alat yang digunakan dalam meningkatkan kualitas pelayanan tersebut terdiri atas berbagai macam tergantung pada organisasi pelayanan tersebut. Alat peningkatan yang digunakan antara lain akreditasi dan Sistem Manajemen Mutu ISO 9000. Akreditasi sendiri merupakan alat yang menekankan pada struktur (Maharani, 2009).Budaya safety juga menjadi aspek penting karena menurut Budiharjo (2008) budaya ini menggambarkan pelayanan yang diberikan dan merupakan salah satu upaya dalam penjaminan mutu.Budaya ini bukan hanya sebatas slogan melainkan secara strategis dikaitkan dengan sistem sosialisasi, strategi SDM, teknologi, pelatihanpelatihan dan keteladanan.

Cable (1998) dalam Bustami

mengungkapkan kunci mengenai mutu pelayanan kesehatan yaitu berpikir secara sistem, pendekatan saintifik, kerjasama tim, kepemimpinan serta peningkatan mutu berkelanjutan. Bustami (2011) menjelaskan berdasarkan pengalamannyaada 6 hal yang dapat dicapai dalam penjaminan mutu.. Pencapaian tersebut adalah: (1) pemeriksaan menjadi lebih teliti, (2) penggunaan sarana dan alat menjadi lebih baik, (3) pengobatan akan lebih tepat 
dan hemat, (4) infomasi untuk pasien akan lebih memadai, (5) pelayanan yang diberikan menjadi lebih ramah dan simpatik sehingga kepercayaan pasien meningkat, (6) hasil akan lebih efektif dan efisien

\section{METODE}

Penelitian ini merupakan penelitian deskriptif observasional dengan pendekatan kuantitatif. Rancangan penelitian ini menurut waktunya adalah desain cross sectional. Pengambilan data dilakukan di Klinik PLK B Unair pada Februari-Maret 2016.

Instrumen yang digunakan adalah Permenkes No. 46 tahun 2015 sebagai pedomandengan observasi dan wawancara.Observasi dilaksanakan dengan panduan assessment dan telusur dokumen.Dokumen yang ditelusur sesuai dengan masing-masing elemen penilaian dari standar akreditasi.Dokumen yang dimaksud secara garis besar dibagi atas dua bagian yaitu dokumen internal dan eksternal.Dokumen internal tersebut berupa kebijakan, pedoman, Standar Operasional Prosedur (SOP), sedangkan dokumen eksternal yaitu peraturan perundangan dan beberpa pedoman.(regulasi) eksternal yang berlaku.Pengambilan data dengan wawancara dilaksanakan untuk mendukung dalam mengklarifikasi telusur terhadap dokumen yang tidak diketahui.Wawancara dilakukan pada petugas PLK B Unairyaitu pelaksana bagian sumber daya manusia, admin dan paramedik.

Analisis data dilakukan dengan memberikan skor pada setiap elemen yang memiliki makna berdasarkan pedoman yaitu 0 (tidak terpenuhi), 5 (terpenuhi sebagian) dan 10 (terpenuhi).Keseluruan pencapaian skor berdasarkan standar akreditasi dikategorikan dalam persentase yaitu $<20 \%$ tidak terpenuhi, $21-79 \%$ terpenuhi sebagian dan $>80 \%$ terpenuhi.

\section{HASIL DAN PEMBAHASAN}

Pengecekan atas elemen penilaian dilakukan untuk mengetahui kesiapan klinik PLK B Unair menghadapi akreditasi klinik pratama.Tabel 1 di bawah menjelaskan secara ringkas hasil pencapaian kesiapan awal PLK B Unair dalam menghadapi akreditasi klinik pratama tahun depan (2017). Standar akreditasi yang disusun dalam empatbab terdapat 394elemen penilaian dengan skor pencapaian saat ini 2.020dari total keseluruhan skor 3.940. Pencapaian saat ini rata-rata keseluruhan standar sebesar $51 \%$,termasuk dalam kategori terpenuhi sebagian.

Standar akreditasi yang memiliki elemen terbanyak terdapat padaBab II Layanan Klinis yang Berorientasi Pasien (LKBP) sebanyak 127 elemen penilaian.Jumlah elemen paling sedikit yaitu 58 elemen penilaian adalah standar akreditasi pada Bab IV Peningkatan Mutu Klinis dan Keselamatan Pasien. Bab IV memiliki jumlah elemen yang paling sedikit harusnya memiliki persentase pencapaian yang lebih tinggi karena probabilitas yang harus dicapai lebih sedikit tetapi pencapaiannya paling rendah yaitu $3 \%$ yang dikategorikan tidak terpenuhi. 
Tabel 1. Hasil Pencapaian PLK Unair B pada Februari 2016 dalam Menghadapi Akreditasi Klinik Pratama menurut Permenkes No. 46 Tahun 2015

\begin{tabular}{|c|c|c|c|c|c|}
\hline BAB & Standar Akreditasi & $\begin{array}{l}\text { Jumlah } \\
\text { Elemen } \\
\text { Penilaian }\end{array}$ & $\begin{array}{c}\text { Jumlah } \\
\text { Skor } \\
\text { Per } \\
\text { elemen } \\
\end{array}$ & $\begin{array}{l}\text { Skor } \\
\text { Pencapaian } \\
\text { Per bab }\end{array}$ & $\begin{array}{l}\text { Persentase } \\
\text { Pencapaian } \\
\text { Per bab }\end{array}$ \\
\hline I & Kepemimpinan dan Manajemen Klinik (KMK) & 122 & 1.220 & 930 & $76 \%$ \\
\hline II & Layanan Klinis yang Berorientasi Pasien (LKBP) & $\begin{array}{r}151 \\
\text { (Opsional } \\
24) \\
\end{array}$ & 1.270 & 755 & $59 \%$ \\
\hline III & Manajemen Penunjang Layanan Klinis (MPLK) & $\begin{array}{r}172 \\
\text { (Opsional } \\
85) \\
\end{array}$ & 870 & 320 & $37 \%$ \\
\hline \multirow[t]{2}{*}{ IV } & Peningkatan Mutu Klinis dan Keselamatan Pasien & 58 & 580 & 15 & $3 \%$ \\
\hline & Total Pencapaian & 394 & 3.940 & 2.020 & $51 \%$ \\
\hline
\end{tabular}

Keterangan : $\left(^{*}\right)$ opsional, penilaian tidak dilakukan pada elemen tersebut dan tidak terhitung pada penilaian.

Standar kriteria Bab I terdiri atas 6 standar,

dan keseluruhan hasil pencapaian yaitu dikategorikan terpenuhi sebagian. Saat pengecekan masih terdapat dokumen yangbelum

tersedia ataupun belum dapat dipastikan apakah dokumen tersebut sudah ada ataukah memang belum dibuat oleh PLK B Unair.Standar yang ditentukan pada bab ini mengenai hal-hal teknis dalam manajemen klinik, secara legalitas klinik belummemenuhi dokumen dan syarat-syarat tersebut. Bab ini menggambarkan kondisi internal dan fisik dari klinik yang akan mempengaruhi mutunya. Mutu tersebut dapat dilihat dari kepuasan pasien sesuai dengan penelitian sebelumnya Widiastuti N. M et. al (2015) menunjukkan dari empat jenis FKTP yang ada kepuasan terendah khususnya dimensi mutu penampilan fisik (tangible) dimiliki oleh klinik pratama jika dibandingkan dengan puskesmas, klinik pemerintah dan praktik dokter pada era JKN saat ini.

Pencapaian elemen terendah pada bab ini yaitu standar kontrak pihak ketiga dimana pencapaiannyahanya sebesar $33 \%$.Pencapaian ini dikategorikan terpenuhi sebagian atau masih banyak dokumen penunjang yang belum dimiliki.Hal ini tentu sangat berdampak secara langsung pada manajemen klinik karena kontraktersebut merupakan salah satu dokumen internal yang berperan untuk menjamin penyelenggaraan pihak ketiga memenuhi standar yang ditetapkan. Keadaan ini belum sesuai dengan pendapat Bustami (2011) dalam upaya penjaminan mutu yaitu pencapaiannya lebih ditekankan pada proses pelayanan yang sesuai dengan standar sehingga mencegah terjadinya pelayanan yang tidak memenuhi standar karena pada akhirnya akan berdampak pada kepuasan pasien.

Pencapaian pada standarbabll yaitu Layanan Klinis yang Berorientasi Pasien (LKBP). Dimana terdapat dua standar kriteria yang tidak dinilai karena termasuk dalam kriteria opsional yaitumengenai (1) makanan dan terapi nutrisi; (2) pemulangan dan tindak lanjut.Kriteria ini opsional sebab dalam pedoman tidak mewajibkan ketersediaannya.PLK B Unair saat ini memang tidak menyediakan layanan rawat inap sehingga standar 
tersebut tidak termasuk dalam penilaian.Pencapaian terendah yaitu pada standar pendidikan kesehatan dan konseling kepada pasien/keluarga.Hal ini dikarenakan karena belum ada tenaga khusus yang memberikan pendidikan kesehatan dan konseling serta belum adanya dokumen dan bukti dokumentasi pelaksanaan pelayanannya.

Elemen penilaian dalam standar kriteria di Bab II mengenai serangkaian proses pelayanan di klinik, .Bustami (2011) mengungkapkan salah satu pencapaian dalam penjaminan mutu yaitu pemeriksaan menjadi lebih teliti. Pencapaian terhadap setiap elemen akan menunjukkan ketelitian dari manajemen dan pelayanan yang diberikan. Ketelitian yang dimaksud disini adalah ketepatan pelayanan yang diberikan dan kesesuaian dengan standar yang ditentukan.Penjaminan mutu sendiri berupaya untuk mencapai bahkan melebihi standar yang ditentukan.

Hasil pencapaian Bab III mengenai Manajemen Penunjang Layanan Klinis.yaitu kelengkapan dokumen dan pemenuhan atas elemen penilaian tersebut dikategorikan terpenuhi sebagian.Jumlah elemen penilaian yang belum terpenuhi cukup besar sehingga perlu mendapat perhatian khusus dalam persiapan akreditasi. Pencapaian rendah dikarenakan PLK B Unair belum menyediakan beberapa pelayanan yang dijadikan standar kriteria sedangkan standar kriteria yang opsional hanya dua yaitu (1) pelayanan laboratorium; (2) radiodiagnostik. Hal tersebut karena dalam pedoman pelayanan bukan merupakan pelayanan penunjang yang wajib dimiliki oleh klinik.
Beberapa elemen dalam bab ini juga tidak memiliki skor atau tidak terpenuhi. Elemen tersebut meliputi lingkungan pelayanan mematuhi persyaratan hukum, regulasi dan perijinan.Hasil wawancara menunjukkan Klinik selama ini tidak pernah melakukan kegiatan maupun pelayanan yang tidak mengindahkan lingkungan tetapi diakui belum menyediakan dokumen terkait hal tersebut sebagai bukti pelaksanaannya. Kondisi ini dapat dihubungkan dengan penelitian sebelumnya Greenfield (2011) mengenai motivasi sumber daya untuk terlibat dalam proses akreditasi dipengaruhi peran para manajer melalui berbagai pendekatan tertentu sehingga sumber daya mau terlibat aktif khususnya dalam pendokumentasian dokumen yang dibutuhkan. Kita ketahui bahwa dalam proses akreditasi hal yang paling dibutuhkan adalah pendokumentasian dokumen yang baik terlebih dahulu kemudian melihat implementasinya. Jika sumber daya di klinik belum memiliki motivasi yang tinggi maka proses akreditasi akan sulit memiliki pencapaian yang tinggi.

Bab IV mengenai Peningkatan Mutu Klinis dan Keselamatan Pasien, hasil penilaiannya sebesar $3 \%$ atau dikategorikan tidak terpenuhi.Jika dilihat dari persentasenya, jumlah elemen penilaian yang belum terpenuhi sangat besar. Hasil tersebut menunjukkan bahwa klinik belum menjalankan standar mengenai keselamatan pasien begitu pula dengan kelengkapan dokumennya.

Pencapaian terendah berada pada standar di bab ini. Penyebabnya sama dengan standar lainnya yaitu klinik belum memiliki beberapa dokumen penunjang yang menjadi bukti pelaksanaannya. Klinik sebaiknya memprioritaskan 
standar dalam bab ini sesuai dengan kunci penjaminan mutu pelayanan kesahan oleh Cable (1998) dalam Bustami (2011), antara lain berpikir secara sistem, pendekatan saintifik, serta peningkatan mutu berkelanjutan.Hal lain yang menjadi perhatian bahwa bab ini mengenai mutu dan keselamatan pasien yang biasanya menjadi keunggulan dari fasilitas kesehatan untuk memperoleh penilaian yang baik di masyarakat sesuai dengan Budiharjo (2008) menyatakan dalam penelitiannya bahwa keselamatan pasien besar pengaruhnya terhadap citra, tanggung jawab sosial, moral serta kinerjanya.

Upaya yang dapat dilakukan dalam meningkatan pencapaian dalam hal keselamatan pasien salah satunya dengan pengelolaan budaya organisasi yang efektif utamanya safety culturesesuai dengan penelitian Budiharjo (2008) agar budaya ini bukan hanya sebatas slogan melainkan secara strategis dikaitkan dengan sistem sosialisasi, strategi SDM, teknologi, pelatihanpelatihan dan keteladanan.

Secara Keseluruhan standar rata-rata pencapaiannya termasuk dalam kategori terpenuhi sebagian.Penilaian yang dilakukan menunjukkan bahwa dari seluruh standar pendokumentasian dokumen banyak yang belum tersedia.Akreditasi tidak hanya melihat pencapaian atas standar tertentu tetapi secara keseluruhan. Hal utama yang perlu diketahui bahwa akreditasi klinik sama halnya dengan akreditasi rumah sakit yang tujuannya untuk meningkatkan mutu pelayanan yang berkesinambungan sehingga sangat diperlukan komitmen bersama dari seluruh sumberdaya yang terdiri dari berbagai macam professional (Poerwani, 2006)

\section{SIMPULAN}

Pencapaian PLK Unair B dalam persiapan akreditasi klinik secara keseluruhan dari 394 elemen penilaian, pencapaian saat ini dengan skor 2.020 dalam persentase sebesar $51 \%$ atau dikategorikan terpenuhi sebagian. Pencapaian terendah yaitu pada standar akreditasi peningkatan mutu klinis dan keselamatan pasien.Pencapaian belum maksimal dikarenakan hampir seluruh dari elemen penilaian yang belum dimiliki adalah ketersediaan dokumen pendukung. Namun dengan adanya penilaian awal ini masih memungkinkan untuk dikembangkan pencapaiannya menjadilebih besar sebelum pelaksanaan akreditasi, mengingat ini adalah penilaian pertama kali menggunakan dasar Permenkes Nomor 46 Tahun 2015 tentang Akreditasi Puskesmas, Klinik Pratama, Tempat Praktik Mandiri Dokter, dan Tempat Praktik Mandiri Dokter Gigi.

Persiapan menghadapi akreditasi klinik yang dapat disarankan yaitu klinik sebaiknya membentuk tim yang khusus mempersiapkan dan melengkapi seluruh dokumen penunjang yang dibutuhkan untuk akreditasi.

\section{DAFTAR PUSTAKA}

Accreditation Commission for Health Care, Inc. (2016). What Accreditation?fromhttp://www.achc.org/getting -started/what-is-accreditation.

Budiharjo, Andreas. (2008). Pentingnya Safety Culture di Rumah Sakit, Upaya meminimalkan Adverse Events. Jurnal Manajemen Bisnis, Volume 1, Nomor 1.

Bustami. (2011). Penjaminan Mutu Pelayanan Kesehatan \&Akseptabilitasnya.Jakarta : Penerbit Erlangga.

Greenfield, David. Marjorie Pawsey \& Jeffrey Braithwaite. 2010. What Motivate professional to engage in the accreditation of healthcare 
organizations?.International Journal for Quality in Health Care 1011: Volume 23, Number 1.

Humas BPJS Kesehatan.(2013). Sejarah Perjalana Jaminan Sosial di Indonesia.Retreived from http://bpjs-

kesehatan.go.id/bpjs/index.php/pages/detail/2 013/4. Last Accesed 11 May 2016.

Humas BPJS Kesehatan. (2016). Pahami Lebih Dalam tentang Sistem Rujukan Berjenjang dan Pola Pembayaran BPJS Kesehatan ke Faskes.Siaran Pers. Retrieved From: https://www.bpjs-

kesehatan.go.id/bpjs/dmdocuments/588c8bcc 7941c2b6d0187435dbcaba61.pdf. Last Accesed 28 July 2016

Hukormas BUK Kemenkes RI. (2015). Diseminasi Hasil Uji Coba Implementasi Akreditasi Puskesmas Di Propinsi Jawa Timur Dan Nusa Tenggara Timur.Retrieved from:http://www.yankes.kemkes.go.id/readdirjen-buk-benahi-sistem-rujukan-yangtersendat-642.html. Last Accesed 28 July 2016

Maharani, C. (2009).Sistem manajemen mutu ISO 9000 sebagai alat peningkatan kualitas organisasi pelayanan kesehatan.Jurnal Kesehatan Masyarakat, 5(1).
Peraturan Menteri Kesehatan Nomor 01 Tahun 2012 tentang Sistem Rujukan Pelayanan Kesehatan Perorangan.

Peraturan Menteri Kesehatan Nomor 46 Tahun 2015 tentang Akreditasi Puskesmas, Klinik Pratama, Tempat Praktik Mandiri Dokter, dan Tempat Praktik Mandiri Dokter Gigi.

PLK Unair. (2015). Laporan Kunjungan PLK Unair 2015. Surabaya : Universitas Airlangga

Poewarni, S.K. and Sopacua, E., (2006). Akreditasi Sebagai Upaya Peningkatan Mutu Pelayanan Rumah Sakit. Buletin Penelitian Sistem Kesehatan, 9(3 Jul).

Shaw, Charles D., et al. (2014). The effect of certification and accreditation on quality management in 4 clinical services in 73 European hospitals.International journal for quality in health care: mzu023.

Undang-Undang Republik Indonesia Nomor 40 Tahun 2004 tentang Sistem Jaminan Sosial Nasional

Widiastuti N.M., N.M Sri Nopiyanti., Nangku Karmya.(2015). Perbedaan Kepuasan Pasien Jaminan Kesehatan Nasional pada Empat Jenis Fasilitas Kesehatan Tingkat pertama.Publich Health and Preventive Medicine Archieve, Volume 3, Nomor 2. 